\title{
KARAKTERISTIK PERTUMBUHAN REMAJA BERDASARKAN EKOSISTEM WILAYAH DI PROVINSI JAWA BARAT
}

\author{
(Growth Characteristics of Adolescents based on Region Ecosystem in West Java Province)
}

\author{
Yudhistira Prasasta $^{1 *}$, Hidayat Syarief ${ }^{1}$, dan Yayuk Farida Baliwati ${ }^{1}$ \\ 'Departemen Gizi Masyarakat, Fakultas Ekologi Manusia (FEMA), Institut Pertanian Bogor, \\ Jl. Raya Darmaga, Bogor 16880
}

\begin{abstract}
The study aimed to analyze growth characteristic of adolescents using height-for-age (HAZ) and BMI-for-age (BAZ) z scores based on regional ecosystem in West Java Province namely coastal area (Cirebon), mountainous area (Bandung), and mixture between coastal and mountainous area (Garut). The design of the study was cross sectional study using secondary data from Riskesdas 2007. Total number of adolescents was 1,674 subjects. The growth characteristics of adolescents in Garut District based on HAZ was correlated with occupation of the head family $(p=0.001 ; r=-0.145)$, while based on BAZ it was correlated with per capita protein intake $(p=0.028 ; r=-0.093)$. Adolescents in Bandung District based on HAZ index correlated with education of the head family $(p=0.040 ; r=0.081)$, occupation of the head family $(p=0.003 ; r=-0.118)$, per capita energy intake $(p=0.031 ; r=-0.085)$, and per capita protein intake $(p=0.002 ; r=-0.124)$, while the $B A Z$ correlated with education of the head of the family $(p=0.017 ; r=0.095)$. Growth characteristics of adolescents in Cirebon District for HAZ was correlated with per capita energy intake $(p=0.044 ; r=-0.086)$, while BAZ was correlated with education of the head family $(p=0.016 ; r=0.102)$.
\end{abstract}

Keywords: adolescents, ecosystem, growth, West Java

\begin{abstract}
ABSTRAK
Penelitian ini bertujuan untuk menganalisis karakteristik pertumbuhan remaja dengan menggunakan indikator TB/U dan IMT/U berdasarkan ekosistem wilayah di Provinsi Jawa Barat yaitu wilayah pantai (Cirebon), pegunungan (Bandung), dan campuran wilayah pantai dan pegunungan (Garut). Desain penelitian ini adalah cross sectional dengan data sekunder Riset Kesehatan Dasar (RISKESDAS) 2007. Jumlah subjek dalam penelitian ini adalah 1674 orang. Karakteristik pertumbuhan remaja di Kabupaten Garut menurut TB/U berkorelasi dengan pekerjaan kepala keluarga $(\mathrm{p}=0.001 ; \mathrm{r}=-0.145)$, dan IMT/U berkorelasi erat dengan asupan protein perkapita $(p=0.028 ; r=-0.093)$. Pada remaja Kabupaten Bandung, karakteristik pertumbuhan TB/U berkorelasi dengan pendidikan kepala keluarga $(p=0.040 ; r=0.081)$, pekerjaan kepala keluarga $(p=0.003 ; r=-0.118)$, asupan energi perkapita $(p=0.031 ; r=-0.085)$, dan asupan protein perkapita $(p=0.002 ; r=-0.124)$ dan untuk IMT/U berkorelasi erat dengan pendidikan kepala keluarga $(p=0.017 ; r=0.095)$. Karakteristik pertumbuhan remaja Kabupaten Cirebon TB/U berkorelasi pada faktor asupan energi perkapita $(p=0.044 ; r=-0.086)$, sementara IMT/U berkorelasi pada pendidikan kepala keluarga $(p=0.016 ; r=0.102)$.
\end{abstract}

Kata kunci: ekosistem, Jawa Barat, pertumbuhan, remaja

"Korespondensi: Departemen Gizi Masyarakat, Fakultas Ekologi Manusia (FEMA), Institut Pertanian Bogor, Jl. Raya Darmaga, Bogor 16880; Email: yudhistira7prasasta@yahoo.com 


\section{PENDAHULUAN}

Tujuan pembangunan nasional adalah terwujudnya masyarakat Indonesia yang sehat dan mandiri. Strategi pencapaian tujuan tersebut adalah melalui Indonesia Sehat 2010 dengan fokus membentuk manusia berkualitas. Salah satu indikatornya adalah manusia yang mampu menikmati hidup sehat, terukur dari angka kesakitan dan kurang gizi. Sejalan dengan itu, tujuan dan arah pembangunan pangan dan gizi adalah perbaikan konsumsi pangan menuju Pola Pangan Harapan Indonesia dan perbaikan status gizi untuk meningkatkan kualitas sumber daya manusia (Depkes RI 2000).

Remaja menurut pengertiannya berasal dari bahasa latin adolesceere yang berarti "tumbuh" atau "tumbuh menjadi dewasa" (Hurlock 2004). Remaja berkisar antara usia 10 sampai dengan 19 tahun. Pada masa remaja ini terjadi pertumbuhan yang cepat baik fisik maupun karakter, sehingga dinilai sangat penting untuk memperhatikan dan mempersiapkan pertumbuhan remaja agar mampu bersaing di masa depan. Pertumbuhan adalah suatu proses perubahan fisiologis yang bersifat progresif, kontinyu dan berlangsung dalam periode tertentu.

Status gizi merupakan keadaan kesehatan tubuh seseorang atau sekelompok orang yang diakibatkan oleh konsumsi, penyerapan (absorbsi), dan penggunaan (utilization) zat gizi makanan. Penilaian status gizi dapat dilakukan dengan dua cara yaitu penilaian status gizi secara langsung maupun tidak langsung. Penilaian status gizi secara langsung meliputi empat cara penilaian yaitu antropometri, klinis, biokimia, dan biofisik. Penilaian status gizi tidak langsung dibagi tiga yaitu survey konsumsi pangan, statistik viral, dan faktor ekologi. Menurut Anwar dan Riyadi (2009), terjadinya masalah gizi tidak hanya disebabkan oleh asupan gizi yang kurang, tetapi juga dipengaruhi oleh penyakit infeksi.

Hasil Riskesdas 2007 menunjukkan tingginya masalah gizi pada kelompok usia remaja. Prevalensi gizi buruk pada remaja di Indonesia sekitar $10.3 \%$. Secara umum laki-laki remaja menunjukkan prevalensi gizi buruk sekitar $13.9 \%$, sedangkan pada wanita berkisar di angka 23.8\%. Data ini menunjukkan jumlah gizi buruk pada wanita lebih tinggi dibanding laki-laki. Faktor pergaulan dan body image diduga memengaruhi asupan makanan dan status gizi remaja wanita. Mereka harus diyakinkan bahwa asupan zat gizi yang kurang akan berakibat pada kesehatannya.

Tujuan penelitian ini secara umum adalah menganalisis karakteristik pertumbuhan remaja berdasarkan ekosistem wilayah di Jawa Barat. Tujuan khusus penelitian ini adalah mengetahui karakteristik pertumbuhan, karakteristik keluarga, asupan gizi, dan status gizi remaja berdasarkan ekosistem wilayah, serta menganalisis faktor-faktor yang berpengaruh terhadap status gizi remaja berdasarkan indeks TB/U dan IMT/U menurut ekosistem wilayah.

\section{METODE}

\section{Desain, Tempat, dan Waktu}

Penelitian mengenai studi karakteristik pertumbuhan remaja di Jawa Barat dilaksanakan dari bulan Desember 2011 dengan menggunakan data Riset Kesehatan Dasar (Riskesdas) 2007. Desain penelitian yang digunakan pada penelitian ini adalah cross-sectional.

\section{Jumlah dan Teknik Penarikan Subjek}

Pemilihan dilakukan secara purposive, yaitu diambil tiga kabupaten di Provinsi Jawa Barat yang memiliki tipologi daerah yang berbeda yaitu Kabupaten Garut, Bandung dan Cirebon. Tipologi daerah masing-masing daerah yaitu Kabupaten Garut terletak disebelah selatan Provinsi Jawa Barat dan merupakan daerah pertanian yang memiliki wilayah pegunungan juga pesisir pantai, Kabupaten Bandung memiliki wilayah yang sebagian besar daerahnya adalah pegunungan, sedangkan Kabupaten Cirebon wilayah berupa dataran rendah/pesisir pantai. Subjek yaitu semua remaja berusia 10-19 tahun yang mempunyai kelengkapan data untuk diteliti. Berdasarkan kriteria inklusi didapat jumlah subjek penelitian ini sebanyak 1674 orang, dengan jumlah subjek dari setiap kabupaten sebagai berikut: Garut 480 orang, Bandung 640 orang, dan Cirebon 554 orang.

\section{Jenis dan Cara Pengumpulan Data}

Data-data yang digunakan dalam penelitian ini merupakan data sekunder, pengumpulan data digunakan dengan cara survei terhadap dinas terkait dan melakukan eksplorasi dari dari data-data yang sudah dipublikasikan secara umum. Jenis data yang dikumpulkan: 1). Karakteristik geografi, demografi, dan potensi arah pembangunan wilayah dari BPS Provinsi Jawa Barat 2010 dan Publikasi Resmi Provinsi Jawa Barat 2012; 2). Karakteristik individu remaja, karakteristik keluarga, dan konsumsi pangan remaja dari Riskesdas 2007.

\section{Pengolahan dan Analisis Data}

Tahapan pengolahan dan analisis data meliputi deskripsi karakteristik geografis wilayah berupa karakteristik wilayah dan letak wilayah secara geografis, deskripsi karakteristik demografis berupa jumlah penduduk dan mata pencaharian, deskripsi potensi arah pembangunan berupa pembagian wilayah dan pengembangan sektor produksi.

Analisis status gizi remaja diukur dengan cara perhitungan z-score (TB/U dan IMT/U) berdasarkan berat badan, tinggi badan, umur, dan jenis kelamin 
dengan menggunakan Software WHO Anthroplus. Analisis karakteristik rumah tangga berupa pengklasifikasian data rumah tangga subjek yaitu besar rumah tangga dan pendidikan orang tua di klasifikasikan menurut BKKBN, pekerjaan kepala keluarga dan pendapatan keluarga menurut BPS Jawa Barat (2010), kemudian dilihat jumlah dan rataratanya serta dihubungkan menurut ekosistem.

Pengolahan data konsumsi diperoleh dari data Riskesdas 2007 dengan metode recall 1×24 jam pada tingkat rumah tangga. Jumlah konsumsi subjek dilakukan dengan pendekatan jumlah konsumsi perkapita yaitu jumlah konsumsi rumah tangga dibagi jumlah keluarga. Untuk melihat variabel mana yang berpengaruh terhadap status gizi dianalisis dengan uji korelasi dan dibandingkan menurut ekosistem.

\section{HASIL DAN PEMBAHASAN}

\section{Karakteristik Individu Remaja}

Jenis kelamin. Subjek yang diperoleh pada penelitian berjumlah 1674 remaja dengan persentase remaja laki-laki berjumlah 856 orang (51.00\%) dan perempuan berjumlah 818 orang $(49.00 \%)$. Jika dibagi berdasarkan wilayah subjek maka didapat sebaran subjek untuk Kabupaten Garut subjek berjenis kelamin laki-laki berjumlah 257 (53.54\%) dan perempuan berjumlah 223 (46.46\%). Kabupaten Bandung terdapat subjek laki-laki berjumlah 328 (5.25\%) dan perempuan sebanyak 312 (48.75\%). Untuk Kabupaten Cirebon terdapat laki-laki sebesar 271 orang $(48.91 \%)$ dan wanita 283 orang (51.19\%).

Umur. Pengelompokan remaja dibagi tiga jenis yaitu remaja awal untuk umur 10-12 tahun, kemudian remaja tengah untuk umur 13-15 tahun, dan remaja akhir untuk umur 16-19 tahun, tiap kelompok umur memiliki karakteristik yang berbeda sehingga perlu untuk dibagi tidak hanya berdasarkan ekosistem wilayah saja. Remaja awal di Garut sebanyak 187 orang (38.96\%), remaja tengah 160 orang (33.33\%), dan remaja akhir berjumlah 133 orang $(27.71 \%)$ sehingga jumlah subjek di Garut sebanyak 480 orang. Untuk jumlah subjek di Bandung sebanyak 640 orang dengan pembagian remaja awal sebanyak 234 orang (36.56\%), remaja tengah 206 orang (32.19\%), dan remaja akhir 200 orang $(31.25 \%)$. Cirebon terdapat subjek sebanyak 554 orang dengan jumlah remaja awal 195 orang (35.20\%), remaja tengah 176 orang (31.77\%), dan remaja akhir 183 orang (33.03\%).

Berat badan dan tinggi badan. Rata-rata berat badan dan tinggi badan di ketiga kabupaten hampir sama dan berada pada rentang rata-rata seluruh subjek. Untuk rata-rata berat badan seluruh subjek adalah $39.8 \pm 11.1 \mathrm{~kg}$, Rata-rata tinggi badan seluruh subjek adalah $145.9 \pm 13.6 \mathrm{~cm}$. Rata-rata berat badan di Kabupaten Garut, Kabupaten Bandung dan Kabupaten Cirebon secara berturut-turut adalah $38.7 \pm 11.1 \mathrm{~kg}, 40.5 \pm 10.6 \mathrm{~kg}$, dan $39.9 \pm 11.5 \mathrm{~kg}$. Rata-rata tinggi badan secara berturut-turut adalah $143.4 \pm 14.6 \mathrm{~cm}, 146.5 \pm 12.9 \mathrm{~cm}$ dan $147.3 \pm 13.2 \mathrm{~cm}$.

\section{Status Gizi}

Status gizi remaja laki-laki ditunjukkan dengan klasifikasi TB/U dan IMT/U dibedakan berdasarkan jenis kelamin (Tabel 1). Klasifikasi TB/U secara keseluruhan subjek di ketiga kabupaten berada pada kategori normal. Remaja awal dengan umur relatif muda memiliki peluang gizi buruk lebih besar dari remaja akhir, untuk itu perlu intervensi dan perhatian lebih menjaga status gizi remaja awal lebih baik dari remaja akhir (Colly et al. 2006). Hanya saja untuk Kabupaten Garut harus mendapatkan perhatian lebih dikarenakan subjek remaja laki-laki yang berada pada kategori sangat pendek cukup besar, bahkan pada kelompok umur 13-15 tahun remaja laki-laki yang masuk kategori sangat pendek

Tabel 1. Persentase Status Gizi Subjek Laki-laki di Ketiga Kabupaten berdasarkan Umur

\begin{tabular}{lccccccccc}
\hline & \multicolumn{1}{c}{ Umur (tahun) } \\
\cline { 2 - 10 } Status Gizi & \multicolumn{3}{c}{ Garut (\%) } & \multicolumn{1}{c}{ Bandung (\%) } & \multicolumn{3}{c}{ Cirebon (\%) } \\
\cline { 2 - 10 } & $10-12$ & $13-15$ & $16-19$ & $10-12$ & $13-15$ & $16-19$ & $10-12$ & $13-15$ & $16-19$ \\
\hline TB/U: & & & & & & & & & \\
-Normal & 56.90 & 58.50 & 51.40 & 71.90 & 61.50 & 69.90 & 68.30 & 77.30 & 61.40 \\
-Pendek & 23.50 & 18.30 & 37.50 & 23.10 & 20.20 & 25.20 & 24.40 & 17.00 & 28.70 \\
-Sangat Pendek & 19.60 & 23.20 & 11.10 & 5.00 & 18.30 & 4.90 & 7.30 & 5.70 & 9.90 \\
IMT/U: & & & & & & & & & \\
-Obesitas & 7.80 & 0.00 & 0.00 & 6.00 & 2.90 & 0.00 & 4.90 & 6.80 & 1.00 \\
-Gemuk & 11.80 & 11.00 & 1.40 & 7.40 & 3.80 & 1.90 & 12.20 & 10.20 & 12.90 \\
-Baik & 65.70 & 73.20 & 88.90 & 81.80 & 76.00 & 82.50 & 72.00 & 76.10 & 82.20 \\
-Kurus & 6.90 & 11.00 & 5.60 & 5.80 & 13.50 & 13.60 & 6.10 & 2.30 & 2.00 \\
-Sangat kurus & 7.80 & 4.90 & 4.20 & 0.00 & 3.80 & 1.90 & 4.90 & 4.50 & 2.00 \\
\hline
\end{tabular}


sampai 23.20\%. Klasifikasi status gizi untuk IMT/U remaja laki-laki berada pada kondisi baik dengan persentase terbesar yaitu sebesar $88.90 \%$. Sementara pada kategori obese subjek terbesar di Kabupaten Garut yaitu pada umur 10-12 tahun sebesar 7.80\%, dan untuk kategori sangat kurus terbesar pada umur 10-12 tahun sebesar $7.80 \%$.

Pengelompokan status gizi remaja pada perempuan dilihat juga melalui klasifikasi TB/U dan IMT/U (Tabel 2). Pada Kabupaten Garut subjek perempuan untuk variabel TB/U untuk kelompok umur 10-12 tahun cukup mengkhawatirkan karena subjek yang masuk kategori sangat pendek mencapai angka $25.00 \%$. Angka ini paling tinggi dibanding kategori umur yang lain sehingga masuk ke dalam titik kritis dan perlu adanya perhatian serius. Subjek perempuan di Kabupaten Bandung berdasarkan status gizi hampir sama dengan Kabupaten Garut. Untuk TB/U terdapat angka yang cukup besar masuk kedalam kategori pendek yaitu untuk kelompok perempuan umur 16-19 tahun, kondisi subjek perempuan di Kabupaten Cirebon status gizi untuk IMT/U pada kategori umur 13-15 tahun dinilai cukup rawan karena persentase subjek kurus mencapai $10.20 \%$ dan untuk yang sangat kurus mencapai 4.50\%. Hal ini kemungkinan merepresentasikan rendahnya intervensi pada remaja tengah dan remaja akhir terhadap kondisi pertumbuhan tubuh.

Analisis ragam digunakan untuk mengetahui perbedaan keragaan status gizi diantara ketiga kabupaten. Untuk indikator TB/U terdapat perbedaan nyata antara Kabupaten Garut dengan Kabupaten Bandung dan Kabupaten Cirebon. Hal ini dilihat dari besarnya selisih nilai status gizi TB/U antara Kabupaten Garut dengan dua kabupaten lainnya. Z-score antara Kabupaten Garut, Kabupaten Bandung, dan Kabupaten Cirebon berturutturut adalah $-1.8614 \pm 1.46827 ;-1.5355 \pm 1.15538$; -1.4976 \pm 1.21174 . Z-score pada Kabupaten Garut lebih kecil daripada dua kabupaten lainnya dimana hal ini menunjukkan bahwa kondisi status gizi subjek di Kabupaten Garut lebih rendah dibanding dua kabupaten lainnya.

Pada indikator IMT/U juga terdapat perbedaan yang cukup signifikan antara Kabupaten Cirebon dengan Kabupaten Garut dan Kabupaten Bandung. Sementara Kabupaten Garut dan Kabupaten Bandung tidak memiliki perbedaan yang nyata. Untuk Kabupaten Garut dan Kabupaten Bandung besarnya z-score adalah $-0.4292 \pm 1.39282$ dan $-0.3922 \pm 1.16480$, sedangkan Kabupaten Cirebon sebesar $-0.7285 \pm 1.29959$ yang artinya status gizi Kabupaten Cirebon dengan indikator IMT/U lebih rendah dibanding Kabupaten Garut dan Bandung. Perbedaan ini mengindikasikan bahwa berat badan dan tinggi badan di Kabupaten Cirebon tidak seimbang.

\section{Karakteristik Keluarga}

Besar keluarga. Data yang diperoleh didapat sebagian besar subjek di ketiga kabupaten memiliki keluarga dengan kategori kecil (Tabel 3), untuk daerah Garut 43.10\% (207 subjek) memiliki kategori keluarga kecil, 40.60\% (195 subjek) keluarga sedang, dan 16.30\% (78 subjek) keluarga besar. Kabupaten Bandung memiliki persentase keluarga kecil, sedang, dan besar masing-masing 50.80\% (325 subjek), 38.60\% (247 subjek), dan 10.60\% (68 subjek). Daerah Cirebon memiliki persentase keluarga kecil, sedang, dan besar masing-masing 38.30\% (212 subjek), $41.50 \%$ (230 subjek), dan 20.20\% (112 subjek).

Pendidikan kepala keluarga. Tabel 3 menunjukkan bahwa untuk daerah Kabupaten Garut memiliki persentase tertinggi kepala keluarga dengan tingkat pendidikan terakhir adalah SD yaitu $41.50 \%$ (199 subjek) sementara untuk perguruan tinggi tidak ada. Daerah Kabupaten Bandung dan Kabupaten Cirebon juga hampir setara yaitu yang terbesar dari tamat SD yaitu untuk Kabupaten Bandung 42.4\% (272 subjek), Kabupaten Cirebon 39.3\% (218 subjek)

Tabel 2. Presentase Status Gizi Subjek Perempuan di Ketiga Kabupaten berdasarkan Umur

\begin{tabular}{lccccccccc}
\hline & \multicolumn{1}{c}{ Umur (tahun) } \\
\cline { 2 - 10 } Status Gizi & \multicolumn{3}{c}{ Garut (\%) } & \multicolumn{3}{c}{ Bandung (\%) } & \multicolumn{3}{c}{ Cirebon (\%) } \\
\cline { 2 - 10 } & $10-12$ & $13-15$ & $16-19$ & $10-12$ & $13-15$ & $16-19$ & $10-12$ & $13-15$ & $16-19$ \\
\hline TB/U: & & & & & & & & \\
-Normal & 58.30 & 53.80 & 68.90 & 75.20 & 78.40 & 61.90 & 70.50 & 65.90 & 71.10 \\
-Pendek & 16.70 & 29.50 & 21.30 & 15.90 & 13.70 & 30.90 & 17.90 & 19.30 & 26.50 \\
-Sangat Pendek & 25.00 & 16.70 & 9.80 & 8.80 & 7.80 & 7.20 & 11.60 & 14.80 & 2.40 \\
IMT/U: & & & & & & & & & \\
-Obesitas & 3.60 & 1.30 & 6.60 & 1.80 & 1.00 & 1.00 & 0.90 & 1.10 & 0.00 \\
-Gemuk & 11.90 & 5.10 & 11.50 & 13.30 & 10.80 & 8.20 & 7.10 & 6.80 & 9.60 \\
-Baik & 77.40 & 87.20 & 78.70 & 80.50 & 82.40 & 89.70 & 77.70 & 77.30 & 88.00 \\
-Kurus & 3.60 & 2.60 & 3.30 & 2.70 & 5.90 & 1.00 & 8.90 & 10.20 & 1.20 \\
-Sangat kurus & 3.60 & 3.80 & 0.00 & 1.80 & 0.00 & 0.00 & 5.40 & 4.50 & 1.20 \\
\hline
\end{tabular}


Tabel 3. Sebaran Subjek berdasarkan Karakteristik Keluarga

\begin{tabular}{|c|c|c|c|c|c|c|c|}
\hline \multirow{3}{*}{ Karakteristik } & \multirow{3}{*}{ Kategori } & \multicolumn{6}{|c|}{ Kabupaten } \\
\hline & & \multicolumn{2}{|c|}{ Garut } & \multicolumn{2}{|c|}{ Bandung } & \multicolumn{2}{|c|}{ Cirebon } \\
\hline & & $\mathrm{n}$ & $\%$ & $\mathrm{n}$ & $\%$ & $\mathrm{n}$ & $\%$ \\
\hline \multirow{4}{*}{ Besar keluarga } & $\leq 4$ orang (kecil) & 207 & 43.10 & 325 & 50.80 & 212 & 38.30 \\
\hline & 5-6 orang (sedang) & 195 & 40.60 & 247 & 38.60 & 230 & 41.50 \\
\hline & >6 orang (besar) & 78 & 16.30 & 68 & 10.60 & 112 & 20.20 \\
\hline & Total & 480 & 100.00 & 640 & 100.00 & 554 & 100.00 \\
\hline \multirow{7}{*}{ Pendidikan KK } & Tidak pernah sekolah & 5 & 1.00 & 10 & 1.50 & 22 & 4.00 \\
\hline & Tidak tamat SD & 168 & 35.00 & 177 & 27.70 & 149 & 26.90 \\
\hline & Tamat SD & 199 & 41.50 & 272 & 42.40 & 218 & 39.30 \\
\hline & Tamat SLTP & 96 & 20.00 & 139 & 21.70 & 125 & 22.50 \\
\hline & Tamat SLTA & 12 & 2.50 & 42 & 6.70 & 38 & 6.80 \\
\hline & Perguruan Tinggi & 0 & 0.00 & 0 & 0.00 & 2 & 0.50 \\
\hline & Total & 480 & 100.00 & 640 & 100.00 & 554 & 100.00 \\
\hline \multirow{13}{*}{ Pekerjaan KK } & Tidak kerja & 29 & 6.00 & 60 & 9.40 & 47 & 8.50 \\
\hline & Ibu rumah tangga & 12 & 2.50 & 17 & 2.70 & 28 & 5.10 \\
\hline & TNI/Polri & 0 & 0.00 & 4 & 0.60 & 8 & 1.40 \\
\hline & PNS & 14 & 2.90 & 43 & 6.70 & 15 & 2.70 \\
\hline & Pegawai BUMN & 2 & 0.40 & 6 & 0.90 & 5 & 0.90 \\
\hline & Pegawai swasta & 6 & 1.30 & 38 & 5.90 & 29 & 5.20 \\
\hline & Wiraswasta/pedagang & 93 & 19.40 & 159 & 24.80 & 132 & 23.80 \\
\hline & Pelayanan Jasa & 9 & 1.90 & 13 & 2.00 & 27 & 4.90 \\
\hline & Petani & 105 & 21.90 & 50 & 7.80 & 77 & 13.90 \\
\hline & Nelayan & 3 & 0.60 & 0 & 0.00 & 6 & 1.10 \\
\hline & Buruh & 194 & 40.40 & 224 & 35.00 & 162 & 29.20 \\
\hline & Lainnya & 13 & 2.70 & 26 & 4.10 & 18 & 3.20 \\
\hline & Total & 480 & 100.00 & 640 & 100.00 & 554 & 100.00 \\
\hline
\end{tabular}

dan terendah adalah perguruan tinggi untuk Kabupaten Bandung 0.00\% dari subjek dan Kabupaten Cirebon $0.50 \%$ ( 2 subjek). Peningkatan pengetahuan gizi remaja yang kemudian diharapkan dapat memperbaiki sikap serta perilaku makan remaja dapat dilakukan melalui peran kepala rumah tangga yang memiliki pengetahuan gizi yang baik, lingkungan seperti kerabat dan sahabat serta lingkungan sekolah yang mendukung (Dwiriani et al. 2011).

Pekerjaan kepala keluarga. Jenis pekerjaan disuatu daerah sedikit banyak dipengaruhi oleh topografi daerah dan ekosistem wilayahnya (Arnelia 2011), hal itu dapat dilihat dari hasil pengolahan data pekerjaan kepala keluarga remaja (Tabel 3). Wilayah ekosistem sawah seperti Kabupaten Garut sebagian besar berprofesi sebagai buruh (40.40\%) dan petani $(21.90 \%)$, selain itu untuk subjek di Kabupaten Cirebon yang merupakan ekologi pesisir. Jumlah pekerjaan orang tua pada nelayan lebih besar daripada kabupaten lain meskipun dari data dilihat sebagian besar berprofesi sebagai buruh (29.20\%) dan pedagang (23.80\%). Sementara untuk Kabupaten Bandung yang merupakan ekosistem da- taran tinggi pegunungan sebagian besar berprofesi buruh $(35.00 \%)$ dan pedagang $(24.80 \%)$.

Pendapatan keluarga. Keluarga di Kabupaten Garut dan Bandung sebagian besar termasuk ke dalam keluarga miskin berturut-turut yaitu $55.20 \%$ dan $51.70 \%$, sedangkan untuk Kabupaten Cirebon sebagian besar termasuk kedalam keluarga tidak miskin sebesar $52.50 \%$. Hasil tersebut menyatakan bahwa pendapatan masyarakat Kabupaten Cirebon lebih tinggi dibandingkan dengan Kabupaten Garut dan Kabupaten Bandung.

Asupan Gizi Remaja Laki-laki. Jumlah asupan gizi remaja laki-laki Kabupaten Garut, asupan energi (Tabel 4) tertinggi berada pada kelompok umur 19 tahun yaitu $1516 \pm 500$ kkal dengan kecukupan sebesar $2550 \mathrm{kkal}$. Asupan energi terbesar pada pada remaja laki-laki Kabupaten Garut berada pada kelompok remaja usia 10-12 tahun dengan tingkat kecukupan sebesar $68.80 \%$. Asupan protein perkapita (Tabel 5) terbesar ada pada kelompok umur 1618 tahun sebesar $48.1 \pm 25.7 \mathrm{mg}$ dan untuk tingkat kecukupannya terbesar berada pada kelompok umur 10-12 tahun sebesar 88.40\%. Kabupaten Bandung, 
Tabel 4. Rata-rata Asupan serta Kecukupan Energi Subjek Laki-Laki berdasarkan Kelompok Umur dan Kabupaten

\begin{tabular}{ccccc}
\hline Kabupaten & Umur & Asupan (kkal) & Kecukupan (kkal) & Tingkat Kecukupan (\%) \\
\hline \multirow{5}{*}{ Garut } & $10-12$ tahun & $1410 \pm 595$ & 2050 & 68.80 \\
& $13-15$ tahun & $1344 \pm 427$ & 2400 & 56.00 \\
& $16-18$ tahun & $1441 \pm 532$ & 2600 & 55.4 \\
& 19 tahun & $1516 \pm 500$ & 2550 & 59.50 \\
\hline \multirow{5}{*}{ Bandung } & $10-12$ tahun & $1477 \pm 565$ & 2050 & 72.00 \\
& $13-15$ tahun & $1401 \pm 462$ & 2400 & 58.40 \\
& $16-18$ tahun & $1428 \pm 419$ & 2600 & 54.90 \\
& 19 tahun & $1600 \pm 589$ & 2550 & 62.70 \\
\hline \multirow{5}{*}{ Cirebon } & $10-12$ tahun & $1380 \pm 422$ & 2050 & 67.30 \\
& $13-15$ tahun & $1382 \pm 493$ & 2400 & 57.60 \\
& $16-18$ tahun & $1429 \pm 468$ & 2600 & 55.00 \\
\hline
\end{tabular}

Tabel 5. Rata-rata Asupan serta Kecukupan Protein Subjek Laki-Laki berdasarkan Kelompok Umur dan Kabupaten

\begin{tabular}{ccccc}
\hline Kabupaten & Umur & Asupan $(\mathrm{g})$ & Kecukupan $(\mathrm{g})$ & Tingkat Kecukupan $(\%)$ \\
\hline \multirow{5}{*}{ Garut } & $10-12$ tahun & $44.2 \pm 24.3$ & 50 & 88.40 \\
& $13-15$ tahun & $41.2 \pm 17.5$ & 60 & 68.70 \\
& $16-18$ tahun & $48.1 \pm 25.7$ & 65 & 74.00 \\
& 19 tahun & $47.9 \pm 24.7$ & 60 & 79.80 \\
\hline \multirow{5}{*}{ Bandung } & $10-12$ tahun & $50.7 \pm 24.8$ & 50 & 101.40 \\
& $13-15$ tahun & $48.6 \pm 20.5$ & 60 & 81.00 \\
& $16-18$ tahun & $49.5 \pm 19.0$ & 65 & 76.20 \\
& 19 tahun & $50.2 \pm 18.7$ & 60 & 83.70 \\
\hline \multirow{5}{*}{ Cirebon } & $10-12$ tahun & $48.8 \pm 28.7$ & 50 & 97.60 \\
& $13-15$ tahun & $47.4 \pm 26.9$ & 60 & 79.00 \\
& $16-18$ tahun & $51.0 \pm 25.5$ & 65 & 78.50 \\
& 19 tahun & $59.7 \pm 31.3$ & 60 & 99.50 \\
\hline
\end{tabular}

asupan energi terbesar pada kelompok umur 19 tahun dengan jumlahnya adalah $1600 \pm 589 \mathrm{kkal}$. Untuk tingkat kecukupan asupan energi terbesar adalah remaja umur 10-12 tahun yaitu sebesar $72.00 \%$. Sementara untuk asupan protein terbesar maupun tertinggi kecukupannya berada pada kelompok usia $10-12$ tahun yaitu sebesar $50.7 \pm 24.8$ g dengan tingkat kecukupan mencapai 101.4\%. Kabupaten Cirebon, asupan energi terbesar pada kelompok umur 19 tahun dengan jumlahnya adalah $1733 \pm 648 \mathrm{kkal}$. Untuk tingkat kecukupan asupan energi terbesar adalah remaja umur 19 tahun yaitu $68.00 \%$. Sementara, asupan remaja laki-laki Kabupaten Cirebon terbesar berada di kategori remaja berumur 19 tahun dengan tingkat kecukupan mencapai $99.50 \%$.

Asupan Gizi Remaja Perempuan. Kabupaten Garut jumlah rata-rata asupan energi perkapita (Tabel 6) terbesar berada pada kelompok umur 10-12 tahun sebesar $1519 \pm 618 \mathrm{kkal}$ serta tingkat kecukupan terbesar adalah kelompok umur 19 tahun yaitu 75.9\%. Asupan protein perkapita (Tabel 7) rata-rata sebesar $49.5 \pm 26.6 \mathrm{~g}$ dan tingkat kecukupan sebesar 99.00\%. Kabupaten Bandung untuk asupan terbesar berada pada remaja perempuan dengan kelompok umur 19 tahun yaitu sebesar $1649 \pm 430 \mathrm{kkal}$ dengan tingkat kecukupan sebesar $86.80 \%$. Kabupaten Bandung memiliki angka rata-rata asupan protein terbaik yaitu berada pada kisaran $95-100 \%$ di semua kelompok umur. Kabupaten Cirebon adalah yang terendah diantara kabupaten lainnya. Jumlah asupan terendah berada pada kelompok umur 16-18 tahun dengan konsumsi rata-rata sebesar $1352 \pm 452$ kkal dan tingkat kecukupan sebesar $61.50 \%$. Asupan protein remaja perempuan di Kabupaten Cirebon terbilang cukup baik meskipun masih dibawah Kabupaten Bandung yaitu dengan kisaran $80-100 \%$ di semua kelompok umur.

Faktor-Faktor yang Berhubungan dengan Status Gizi di Setiap Kabupaten

Kabupaten Garut. Kabupaten Garut untuk status gizi berdasarkan TB/U didapat faktor yang 
Tabel 6. Rata-rata Asupan serta Kecukupan Energi Subjek Perempuan berdasarkan Kelompok Umur dan Kabupaten

\begin{tabular}{ccccc}
\hline Kabupaten & Umur & Asupan (kkal) & Kecukupan (kkal) & Tingkat Kecukupan (\%) \\
\hline \multirow{6}{*}{ Garut } & $10-12$ tahun & $1519 \pm 618$ & 2050 & 74.10 \\
& $13-15$ tahun & $1381 \pm 494$ & 2350 & 58.80 \\
& $16-18$ tahun & $1343 \pm 489$ & 2200 & 61.10 \\
& 19 tahun & $1441 \pm 609$ & 1900 & 75.90 \\
\hline \multirow{5}{*}{ Bandung } & $10-12$ tahun & $1521 \pm 552$ & 2050 & 74.20 \\
& $13-15$ tahun & $1579 \pm 539$ & 2350 & 67.20 \\
& $16-18$ tahun & $1352 \pm 450$ & 2200 & 61.50 \\
& 19 tahun & $1649 \pm 430$ & 1900 & 86.80 \\
\hline \multirow{5}{*}{ Cirebon } & $10-12$ tahun & $1433 \pm 403$ & 2050 & 69.90 \\
& $13-15$ tahun & $1458 \pm 554$ & 2350 & 62.10 \\
& $16-18$ tahun & $1352 \pm 452$ & 2200 & 61.50 \\
& 19 tahun & $1368 \pm 839$ & 1900 & 72.00 \\
\hline
\end{tabular}

Tabel 7. Rata-rata Asupan serta Kecukupan Protein Subjek Perempuan berdasarkan Kelompok Umur dan Kabupaten

\begin{tabular}{ccccc}
\hline Kabupaten & Umur & Asupan $(\mathrm{g})$ & Kecukupan $(\mathrm{g})$ & Tingkat Kecukupan (\%) \\
\hline \multirow{5}{*}{ Garut } & $10-12$ tahun & $48.0 \pm 25.3$ & 50 & 96.00 \\
& $13-15$ tahun & $42.3 \pm 21.0$ & 57 & 74.20 \\
& $16-18$ tahun & $43.5 \pm 20.3$ & 50 & 87.00 \\
& 19 tahun & $49.5 \pm 26.6$ & 50 & 99.00 \\
\hline \multirow{5}{*}{ Bandung } & $10-12$ tahun & $51.7 \pm 21.7$ & 50 & 103.40 \\
& $13-15$ tahun & $56.0 \pm 24.7$ & 57 & 98.20 \\
& $16-18$ tahun & $47.5 \pm 19.9$ & 50 & 95.00 \\
& 19 tahun & $57.8 \pm 18.6$ & 50 & 115.60 \\
\hline \multirow{5}{*}{ Cirebon } & $10-12$ tahun & $48.3 \pm 22.4$ & 50 & 96.60 \\
& $13-15$ tahun & $48.3 \pm 22.8$ & 57 & 84.70 \\
& $16-18$ tahun & $47.2 \pm 18.7$ & 50 & 94.40 \\
& 19 tahun & $50.1 \pm 36.5$ & 50 & 100.20 \\
\hline
\end{tabular}

berhubungan nyata adalah pekerjaan rumah tangga dengan $p<0.05(p=0.001 ; r=-0.145)$. Sementara jumlah keluarga, jumlah pendapatan, pendidikan kepala keluarga, asupan energi perkapita, dan asupan protein perkapita tidak memiliki hubungan yang nyata. Indikator status gizi IMT/U untuk Kabupaten Garut memiliki hubungan nyata dengan asupan protein perkapita dengan $p<0.005(p=0.028 ; r=-0.093)$. Faktor-faktor lainnya seperti jumlah keluarga, jumlah pendapatan, pendidikan kepala keluarga, pekerjaan kepala keluarga, dan asupan energi tidak memiliki hubungan yang nyata.

Kabupaten Bandung. Selain faktor internal, faktor eksternal remaja juga sangat memengaruhi status gizinya (Wang et al. 2012). Faktor-faktor yang memiliki hubungan nyata dengan status gizi TB/U di Kabupaten Bandung dengan adalah pendidikan kepala keluarga $(p=0.040 ; r=0.081)$, pekerjaan kepala keluarga $(p=0.003 ; r=-0.118)$, asupan energi $(p=0.031 ; r=-0.085)$, dan konsumsi protein perkapita $(p=0.002 ; r=-0.124)$. Sementara yang tidak memiliki hubungan nyata adalah faktor jumlah keluarga serta jumlah pendapatan keluarga. Status gizi IMT/U di Kabupaten Bandung adalah pendidikan kepala keluarga yang berhubungan nyata $(p=0.017 ; r=0.095)$. Faktor yang tidak memiliki hubungan nyata adalah jumlah keluarga, jumlah pendapatan, pekerjaan kepala keluarga, asupan energi, dan asupan protein.

Kabupaten Cirebon. Di Kabupaten Cirebon faktor yang berhubungan nyata dengan status gizi $\mathrm{TB} / \mathrm{U}$ adalah asupan energi $(\mathrm{p}=0.044 ; \mathrm{r}=-0.086)$. Faktor yang tidak memiliki hubungan nyata adalah jumlah keluarga, jumlah pendapatan, pendidikan kepala keluarga, pekerjaan kepala keluarga, dan asupan protein. Status gizi IMT/U di Kabupaten Cirebon adalah pendidikan kepala keluarga yang berhubungan $(p=0.016 ; r=0.102)$. Faktor yang tidak memiliki hubungan nyata adalah jumlah keluarga, jumlah pendapatan, pekerjaan kepala keluarga, asupan energi, dan asupan protein. 


\section{KESIMPULAN}

Karakteristik keluarga di Kabupaten Garut dan Bandung sebagian besar berada di kelas keluarga kecil, sementara untuk di Kabupaten Cirebon berada di kelas keluarga sedang. Untuk kepala keluarga subjek ketiga kabupaten pendidikan terakhir kepala keluarga adalah tamat SD dengan pekerjaan berbeda-beda dilihat dari potensi ekosistemnya. Untuk Kabupaten Garut sebagian besar berpofesi sebagai buruh dan petani, untuk Kabupaten Bandung mayoritas adalah buruh dan pedagang sementara Kabupaten Cirebon kebanyakan berprofesi sebagai buruh dan pedagang. Jumlah subjek yang masuk kategori miskin dan tidak miskin di ketiga kabupaten cukup berimbang, persentase keluarga miskin untuk Kabupaten Garut, Bandung, dan Cirebon sebesar 55.2\%, 51.7\%, dan 47.5\%. Mayoritas subjek yang masuk kategori miskin adalah keluarga dengan pendidikan kepala keluarga sampai lulus SD saja.

Status gizi remaja di ketiga kabupaten berdasarkan IMT/U sebagian besar masuk kedalam kategori baik, tapi jika digabung dengan TB/U maka status gizi yang baik tapi sangat pendek cukup besar, ini membuktikan bahwa karakteristik individu remaja subjek jika dilihat berat badannya menurut umur berada dalam kondisi ideal. Hanya saja jika dilihat tinggi badannya ternyata cukup banyak remaja subjek yang masih berada dalam status pendek atau sangat pendek. Kabupaten Garut, Bandung, dan Cirebon secara persentase yang berstatus gizi baik namun sangat pendek berturut-turut adalah 11.7, 5.5, dan 6.0. Hasil analisis ragam berdasarkan ekosistem memperlihatkan bahwa status gizi menurut TB/U Kabupaten Garut berbeda nyata dengan Kabupaten Bandung dan Cirebon, sedangkan menurut IMT/U Kabupaten Cirebon berbeda nyata dengan Kabupaten Garut dan Bandung.

Faktor yang berhubungan dengan status gizi $(p<0.05)$ di Kabupaten Garut yaitu pendidikan kepala keluarga, pekerjaan kepala keluarga, dan asupan protein remaja. Untuk Kabupaten Bandung faktor yang memengaruhi adalah jumlah pendapatan, pendidikan kepala keluarga, pekerjaan kepala keluarga, serta konsumsi energi dan protein perkapita remaja. Untuk Kabupaten Cirebon faktor yang memengaruhi adalah pendidikan kepala keluarga dan asupan energi remaja.

Saran yang diberikan bahwa sebagian besar remaja kurang dalam hal asupan energi hal ini menjadi perhatian serius pemenuhan konsumsi semenjak dari rumah tangga yaitu orang tua sampai pada pemenuhan kebutuhan energi di tingkat wilayah. Kondisi ekonomi juga menjadi faktor serius permasalahan konsumsi yang berdampak pada pertumbuhan remaja terutama dari pekerjaan kepala keluarga dan penghasilan keluarga. Masih banyaknya remaja yang tergolong kategori sangat pendek berdasarkan tinggi badan per umur adalah masalah gizi yang serius dan menjadi perhatian keluarga serta pemerintah dalam memperbaiki pertumbuhan fisik remaja. Informasi konsumsi remaja yang masih menggunakan pendekatan konsumsi perkapita menyebabkan analisis menjadi kurang tajam dan tidak representatif dalam memberikan hasil analisis.

\section{DAFTAR PUSTAKA}

Anwar F \& Riyadi H. 2009. Status gizi dan status kesehatan suku baduy. Jurnal Gizi dan Pangan, $4(2), 72-82$.

Arnelia. 2011. Adolescent Characteristics with the Severe Malnutrition and Linear Growth Disorder History in Early Age. Journal of Nutrition and Food, 6(1), 42-50.

Briawan D, Febriani NPS, \& Hardinsyah. 2012. Minuman berkalori dan kontribusinya terhadap total asupan energi remaja dan dewasa. Jurnal Gizi dan Pangan, 7(1), 35-42.

Coly AN, Milet J, Diallo A, Ndiaye T, Eric B, Simondon F, Wade S, \& Simondon KB. 2006. Preschool stunting, adolescent migration, catch-Up growth, and adult height in young Senegalese men and women of rural origin. Journal of Nutrition, 136, 2412-2420.

[Depkes] Departemen Kesehatan. 2000. Buku Petunjuk Pelaksanaan Cara Pengisian KMS Anak Sekolah Dasar Ibtidaiyah. Direktorat Bina Gizi Masyarakat, Jakarta.

Dwiriani CM, Rimbawan, Hardinsyah, Riyadi H, \& Martianto D. 2011. Pengaruh pemberian zat multi gizi mikro dan pendidikan gizi terhadap pengetahuan gizi, pemenuhan zat gizi dan status besi remaja putri. Jurnal Gizi dan Pangan, 6(3), 171-177.

Hurlock EB. 2004. Psikologi Perkembangan. Erlangga, Jakarta.

McGregor SG, Cheung YB, Cueto S, Glewwe P, Richter L, \& Strupp B. 2007. Developmental potential in the first 5 years for children in developing countries. Lancet, 369, 60-70.

Walker SP, Chang SM, Powell CA, Simonoff E, \& McGregor SMG. 2007. Early childhood stunting is associated with poor psychological functioning in late adolescence and effects are reduced by psychosocial stimulation. Journal of Nutrition, 137, 2464-2469.

Wang Y, Bentley ME, Zhai F, \& Popkin BM. 2002. Tracking of dietary intake patterns of Chinese from childhood to adolescence over a sixyear. Journal of Nutrition, 132, 430-438. 